\title{
The Effects of Neutrophil-Lymphocyte Ratio, Platelet-Lymphocyte Ratio and Prognostic Markers in Determining the Mortality in Patients Diagnosed With Pneumonia in Intensive Care
}

\author{
Yoğun Bakımda Pnomoni Tanılı Hastalarda Nötrofil-Lenfosit Oranının, \\ Trombosit-Lenfosit Oranının ve Prognostik Belirteçlerin Mortaliteyi \\ Belirleme Üzerine Etkileri
}

\section{Omer Faruk ALTAS $\odot$, Mehmet KIZILKAYA $\odot$}

Ethics Committee Approval: This study was approved by İzmir Katip Çelebi University Ethics Committee, 23 May 2018, 192.

Conflict of interest: The authors declare that they have no conflict of interest.

Funding: None.

Informed Consent: Informed consents were taken from the participants of the study.
Cite as: Altaş OF, Kizilkaya $M$. The effects of neutrophil-lymphocyte ratio, platelet-lymphocyte ratio and prognostic markers in determining the mortality in patients diagnosed with pneumonia in intensive care. Medeni Med J. 2021;36:130-7.

\begin{abstract}
Objective: In this study, we aimed to reveal the level of predicting mortality of the Neutrophil/Lymphocyte (NLR) and Platelet/Lymphocyte Ratios (TLR) calculated in patients hospitalized with the diagnosis of pneumonia in the intensive care unit when compared with other prognostic scores.

Method: The hospital records of 112 patients who were admitted to the intensive care unit between January 2015 and January 2018 and met the inclusion criteria were retrospectively reviewed. The patients' demographic data, the NLR and PLR levels, and the APACHE II (Acute Physiology and Chronic Health Evaluation II) and SOFA (Sequential Organ Failure Assessment) scores were calculated from the patient files.

Results: Of the 112 patients examined, 70 were males. The risk analysis showed that the male gender had 2.7 times higher risk of mortality. The NLR, PLR, APACHE II, and SOFA values were found statistically significant in predicting mortality $(p<0.001)$. An evaluation of the risk ratios demonstrated that each one point increase in the NLR increased the mortality risk by 5\%, and each one point increase in the SOFA score increased the mortality risk by $13 \%(p<0.05)$. In the ROC (receiver operating characteristic) analysis, the NLR assessment proved to be the most powerful, most specific, and sensitive test. The cut-off values were 11.3 for the NLR, 227 for the PLR, 29.8 for the APACHE II scores, and 5.5 for the SOFA scores.

Conclusion: We believe that NLR and PLR are strong and independent predictors of mortality that can be easily and cost-effectively tested.
\end{abstract}

Keywords: Mortality, neutrophil-to-lymphocyte ratio, platelet-to-lymphocyte ratio, pneumonia, prognosis

öz

Amaç: Bu çalışmada, yoğun bakıma pnömoni tanısı ile yatııılmış hastalarda hesaplanan Nötrofil/Lenfosit Oranı (NLO) ve Trombosit/Lenfosit Oranı (TLO)'nun; diğer prognostik skorlarla karşılaştırıldığında mortaliteyi belirleme düzeyini ortaya koymak amaçlanmıștır.

Yöntem: Ocak 2015 ile Ocak 2018 arasında yoğun bakım ünitesine kabul edilen ve çalışmamıza dahil olma kriterlerini sağlayan toplam 112 hastanın hastane kayıtları retrospektif olarak incelendi. Demografik veriler kaydedildi; NLO, TLO, APACHE II (Akut Fizyoloji ve Sağllk Değerlendirmesi Skoru II) ve SOFA (Ardışık Organ Yetmezliği Değerlendirme Skoru) skorları kayıtlardan hesaplandı.

Bulgular: Incelenen 112 hastanın 70'i erkekti. Bakılan risk analizinde erkek cinsiyetin 2, 7 kat daha fazla mortalite riskine sahip olduğu anlassıldı. NLO, TLO. APACHE II ve SOFA'nın mortaliteyi belirlemede istatistiksel olarak anlamlı olduğu tespit edildi $(p<0,001)$. Risk oranlarına bakıldığında her 1 birim NLO'nın $\% 5$, SOFA'nın ise \%13 mortalite riskini artırdlğı belirlendi $(p<0,05)$. Yapılan ROC (Alıcl işletim karakteristiği) analizinde ise NLO en güclü, en spesifik ve sensitif test olarak bulundu. Cut-off değerleri; NLO'nun 11,3, APACHE II'nin 29,8, TLO'nun 227 ve SOFA'nin ise 5,5 olarak belirlendi.

Sonuç: NLO ve TLO'nun iyi bir mortalite belirleyicisi olmakla birlikte, basit, ucuz, hızlı ve bağımsız bir gösterge olduğunu düşünmekteyiz.

Anahtar kelimeler: Mortalite, nötrofil/lenfosit oranı, pnömoni, prognoz, trombosit/lenfosit oranı
Received: 11 April 2021

Accepted: 29 May 2021

Online First: 18 June 2021

Corresponding Author:

O.F. Altas

ORCID: 0000-0001-7016-4500 Izmir Bakircay University

Cigli Training and Research Hospital, Department of Anesthesiology and Reanimation, Izmir, Turkey

omerfarukaltas@hotmail.com

M. Kizilkaya ORCID: 0000-0002-3767-2367 Amasya University Sabuncuoğlu Serafettin Training and Research Hospital, Department of Anesthesiology and Reanimation, Amasya, Turkey 
O.F. Altas and M. Kizilkaya, The Effects of Neutrophil-Lymphocyte Ratio, Platelet-Lymphocyte Ratio and Prognostic Markers in Determining the Mortality in Patients Diagnosed With Pneumonia in Intensive Care

\section{INTRODUCTION}

Scoring systems in the intensive care unit have been in use for a long time to determine the severity of the disease and to predict the morbidity and mortality rates ${ }^{1}$. Several studies to date have shown the effectiveness of the scoring systems in predicting hospital mortality, and most of the available scores predict the prognosis in a comparable fashion ${ }^{2,3}$. Currently available prognostic scoring systems such as the Acute Physiology and Chronic Health Evaluation II (APACHE II) score and the Sequential Organ Failure Assessment (SOFA) score showed their utility in the prediction of mortality ${ }^{4}$.

In addition, it was shown that the Neutrophilto-Lymphocyte ratio (NLR) and the Platelet-toLymphocyte ratio (PLR) can be used as markers of inflammation in many different diseases, including pneumonia and bacteremia ${ }^{5}$. Based on increasing evidence, researchers reported about the effectiveness of the NLRin the prediction of survival in various diseases such as colorectal cancer, lung cancer, orthotopic liver transplantation in primary hepatocellular carcinoma, chronic heart failure, postoperative coronary artery bypass grafting, pulmonary embolism, and acute pancreatitis ${ }^{6,7}$.

Changes in the immune system constitute the main backbone of the pathophysiology of sepsis. Therefore, NLR and PLR have emerged as potential new biomarkers in sepsis ${ }^{8,9}$. Since, NLR and PLR are simple, affordable, and easily performed tests, their use in intensive care units is more appealing ${ }^{10}$.

Patients diagnosed with pneumonia and hospitalized in intensive care units generally have high morbidity and mortality rates ${ }^{11}$. It was assumed that, when compared to the APACHE II or SOFA scores, inflammation-based markers such as the NLR and PLR would better predict in-hospital mortality among patients admitted to the intensive care units with the diagnosis of pneumonia.
In this study our aim was to compare the inflammation-based prognostic scores with other prognostic scores as predictors of mortality in patients diagnosed with pneumonia.

\section{MATERIAL and METHODS}

A total of 112 patients (42 females and 70 males) over 18 years of age who met the inclusion criteria, and were admitted to the Intensive Care Unit at the Department of Anesthesiology and Reanimation at Atatürk Training and Research Hospital of Izmir Katip Çelebi University between January 2015 and January 2018 were retrospectively reviewed. Hospital information management system records, archives, and file records of the 112 patients were analyzed retrospectively. The approval for our study, dated May 23, 2018 and numbered 192 , was obtained from the Non-Interventional Clinical Research Ethics Committee of the Faculty of Medicine at Izmir Katip Çelebi University.

Patients admitted to the intensive care unit after being diagnosed with pneumonia and underwent routine laboratory examinations were included in the study. Patients under 18 years of age, pregnants, or had a hematological disease, chronic liver disease, or immunosuppressive disease (AIDS, etc.), and those who had received immunosuppressive therapy within the last month (chemotherapy, chronic steroid use, and autoimmune disease treatment), those that had cardiac arrest during intensive care admission, or got blood transfusion within the last two weeks were excluded from the study.

Hundred and twelve patients included in the study were divided into two groups; deceased patients (Group 1: $\mathrm{n}=64$ ) and survivors (Group 2: $n=48$ ). The age, gender, and other demographic data of all patients were recorded. The neutrophil counts in the blood samples taken during the patients' hospitalization in the intensive care unit were divided by the number of lymphocytes to find the NLR, and the platelet counts were divided 
by the number of lymphocytes to find the PLR. In addition, the APACHE II and SOFA scores of all patients were calculated.

The APACHE II scoring system consists of three sections: Acute physiology score, chronic health status, and age. All scores in the three sections are calculated. Mortality rate is determined by adding the age, past health status and surgical intervention experienced (if any) to this calculation ${ }^{12}$.

In the SOFA scoring system, the cardiovascular, neurological, liver, renal, respiratory, and coagulation systems are evaluated, with zero being the top and four the worst score. A score of three or four in a system indicates that the rate of organ failure risk is high in that system ${ }^{13,14}$.

\section{Statistical analyses}

The statistical analyses in our study were performed using the IBM SPSS v.22.0 software. Descriptive statistics were used to determine the patients' characteristics, while the chi-square, frequency, and the Mann-Whitney $U$ tests were utilized in comparing the patient groups. The Receiver Operating Characteristic (ROC) curve analysis was used when comparing the scoring systems. Besides the Cox regression test was used in risk analyses, the Pearson and the Spearman correlation tests in correlation analyses, and the Kaplan-Meier test in survival analyses. A $p$ value of less than 0.05 was considered to be statistically significant. Since our study is a crosssectional study, when a retrospective sample size analysis was performed in the OpenEpi software to determine whether 112 patients studied were a sufficient cohort size, it was determined that 58 patients were enough to conduct the study with a confidence interval of $95 \%$ and a power of $90 \%$, and that this value was compatible with the number of patients in this study.

\section{RESULTS}

The demographic data of the patients are summarized in Table 1. Forty-two (37.5 \%) female, and $70(62.5 \%)$ male patients were included in the study. Group 1 included 44 male and 20 female, while Group 2 consisted of 26 male and 22 female patients. When the demographic data were compared, there was a statistically significant relationship between the groups in terms of Chronic Obstructive Pulmonary Disease (COPD) and sepsis at admission $(p=0.003$ and $\mathrm{p}=0.003$, respectively) (Table 1 ).

Table 1. The demographic and clinical characteristics of the groups.

\begin{tabular}{llll}
\hline Variables & $\begin{array}{l}\text { Group 1 } \\
\text { (n=64) }\end{array}$ & $\begin{array}{l}\text { Group 2 } \\
(\mathbf{n = 4 8 )}\end{array}$ & $\mathbf{p}^{*}$ \\
\hline Age $^{\dagger}$ & $70.72 \pm 16.84$ & $69.65 \pm 13.18$ & 0.270 \\
$\begin{array}{l}\text { Gender } \\
\text { Male }\end{array}$ & $44(71 \%)$ & $26(54.2 \%)$ & \\
Female & $20(29 \%)$ & $22(45.8 \%)$ & 0.115 \\
DM & $16(25.0 \%)$ & $13(27.1 \%)$ & 0.803 \\
Hypertension & $34(53.1 \%)$ & $24(50.0 \%)$ & 0.743 \\
COPD & $42(65.6 \%)$ & $18(37.5 \%)$ & 0.003 \\
Sepsis & $31(48.4 \%)$ & $10(20.8 \%)$ & 0.003 \\
Hospitalization with & $37(57.8 \%)$ & $21(43.8 \%)$ & 0.121 \\
mechanical ventilator & & & \\
support & & & \\
\end{tabular}

DM: Diabetes Mellitus, COPD: Chronic Obstructive Pulmonary Disease. *Pearson's chi-square analysis, ${ }^{\dagger}$ Frequency and the Mann-Whitney $U$ test. Statistically significant $p$ values are written in bold.

Table 2. Distribution of the mean scores according to the groups.

\begin{tabular}{llll}
\hline & $\begin{array}{l}\text { Group 1 }(\mathbf{n}=64) \\
\text { Mean } \pm \text { SD }\end{array}$ & $\begin{array}{l}\text { Group 2 }(\mathbf{n}=48) \\
\text { Mean } \pm \text { SD }\end{array}$ & p \\
\hline SOFA & $7.33 \pm 3.11$ & $5.25 \pm 2.39$ & $<0.001$ \\
APACHE II & $41.33 \pm 14.42$ & $29.20 \pm 15.97$ & $<0.001$ \\
NLR & $22.16 \pm 13.75$ & $8.88 \pm 6.73$ & $<0.001$ \\
PLR & $480.35 \pm 426.06$ & $219.19 \pm 152.50$ & $<0.001$ \\
\hline
\end{tabular}

APACHE II: Acute Physiology and Chronic Health Evaluation II Score, NLR: Neutrophil-to-Lymphocyte Ratio, PLR: Plateletto-Lymphocyte Ratio, SD: Standard Deviation, SOFA: Sequential Organ Failure Assessment Score . ${ }^{*}$ Frequency and Mann-Whitney $U$ test. Significant $p$ values are written in bold.

In the evaluation of the hazard ratio of the demographic data, we found that the risk of death was statistically significant higher i.e. 2.73 times in males than females, $(p<0.05)$. The mean survival 
time of males in Group 1 was $12 \pm 2.36$ days and a statistically significant difference between two groups was detected $(p<0.05)$. The mean survival time of males in Group 2 was $14 \pm 3.56$ days without any statistically significant difference between the groups ( $p>0.05)$. The mean value distributions of the scoring systems are shown in Table 2.

Each one point increase in the NLR increased the mortality risk by $5 \%$, and each one point increase in the SOFA scores increased the mortality risk by $13 \%$ ( $p<0.05)$. In the ROC analysis, the SOFA score was the least significant score against the APACHE II score, NLR and PLR (Figure 1). According to the cut-off value of 5.5, the SOFA scores had the sensitivity of $64.1 \%$ and the specificity of $60.4 \%$. The APACHE II score was determined to be a more powerful scoring system but a weaker factor than the NLR in predicting mortality (Figure 1 ). According to the cut-off value of 29.8 , the APACHE II score had the sensitivity of $81.3 \%$ and the specificity of $64.6 \%$.

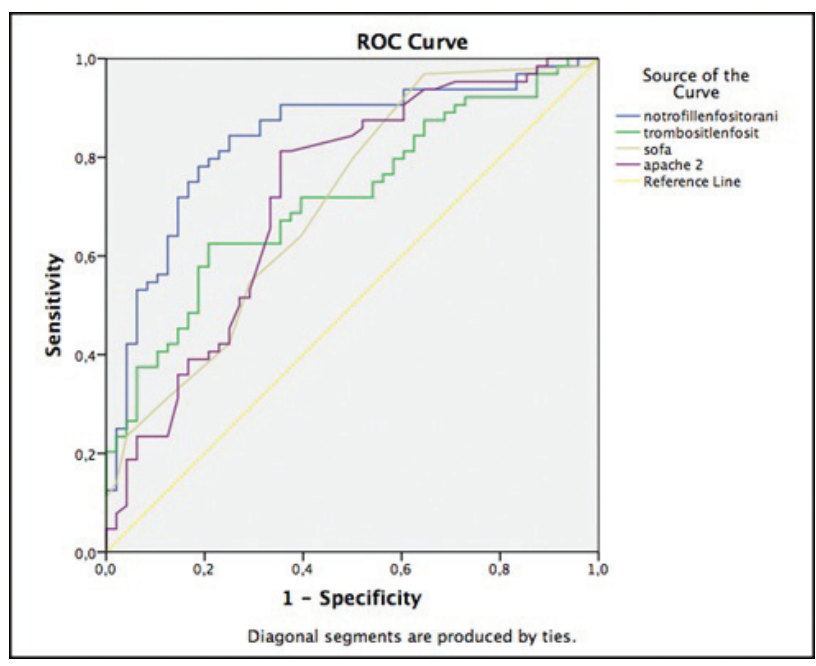

Figure 1. The NLR, PLR, APACHE II and SOFA values, and the ROC curve.

In the evaluation of the Area Under the Curve (AUC) in ROC analysis, the NLR was found to be the most powerful tool against APACHE II, PLR and SOFA, respectively in predicting mortality. The utility of PLR in predicting mortality was between the APACHE II and SOFA scores $(p<0.001)$ (Figure
1). While the NLR had $81.3 \%$ sensitivity and $77.1 \%$ specificity according to the cut-off value of 11.3 , the PLR had $67.2 \%$ sensitivity and $62.5 \%$ specificity according to the cut-off value of 227 . The mean survival times according to the NLR and the PLR cut-off values are shown in Table 3 , and in Figures 2 and 3.

Table 3. Average survival times (days) according to the NLR cut-off (11.3) and the PLR cut-off (227) values.

\begin{tabular}{|c|c|c|c|}
\hline NLR cut-off & $\mathbf{n}$ & Mean \pm SD & $95.0 \% \mathrm{CI}^{*}$ \\
\hline$<11.3$ & 49 & $160 \pm 52.09$ & $57.88-262.11$ \\
\hline$>11.3$ & 63 & $15 \pm 3.15$ & $8.81-21.18$ \\
\hline PLR cut-off & $\mathbf{n}$ & Mean \pm SD & $95.0 \% \mathrm{CI}^{*}$ \\
\hline$<227$ & 51 & $47 \pm 19.32$ & $9.12-84.87$ \\
\hline$>227$ & 61 & $22 \pm 4.44$ & $13.29-30.70$ \\
\hline
\end{tabular}

The Kaplan-Meier Survival Analysis. ${ }^{*} \mathrm{CI}$ : Confidence Interval, NLR: Neutrophil-to-Lymphocyte Ratio, PLR: Platelet-toLymphocyte Ratio, SD: Standard Deviation.

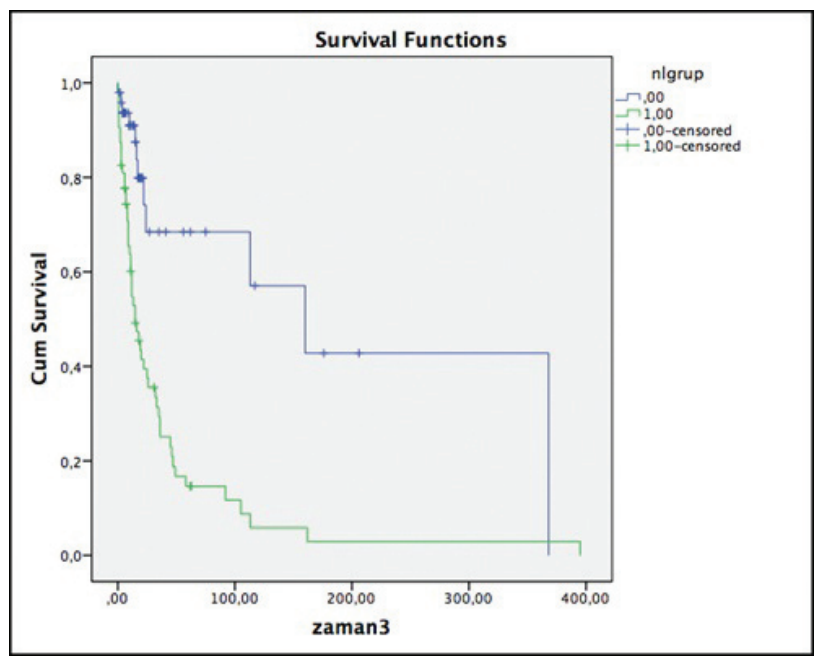

Figure 2. Average survival time in days according to the NLR cut-off value of 11.3 in Kaplan-Meier analysis.

According to the correlation analyses performed in our study (Table 4), weak positive correlations were detected between the white blood cell (WBC) count and the NLR; the APACHE II score and both WBC, and the NLR; the NLR and both the SOFA score, and age. On the other hand, a weak negative correlation existed between the mean platelet volume (MPV) and the PLR. A weak correlation was found between the female gender 
and the SOFA scores. The Glasgow Coma Score (GCS) was negatively correlated with the SOFA and APACHE II scores, while the APACHE II score was positively correlated with the SOFA score.

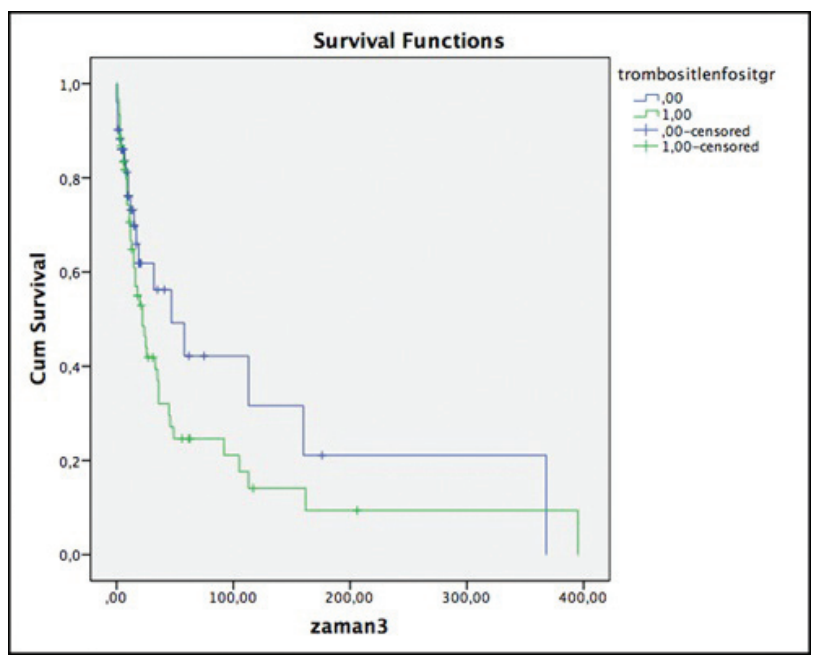

Figure 3. Average survival time in days according to the PLR cut-off value of $\mathbf{2 2}$ in Kaplan-Meier analysis.

Table 4. Correlations among the factors tested using the Pearson/Spearman correlation tests.

\begin{tabular}{lccll}
\hline Variables & NLR & PLR & APACHE II & SOFA \\
\hline WBC & $0.331^{\dagger}$ & -0.004 & $0.255^{\dagger}$ & 0.108 \\
RDW & 0.141 & 0.031 & 0.077 & 0.063 \\
MPV & -0.009 & $-0.263^{\dagger}$ & 0.082 & 0.058 \\
Age & $0.233^{*}$ & 0.057 & $0.316^{\dagger}$ & $0.218^{*}$ \\
Gender & -0.164 & -0.155 & -0.055 & $-0.229^{*}$ \\
GCS & -0.144 & -0.021 & $-0.617^{\dagger}$ & $-0.679^{\dagger}$ \\
APACHE II & $0.252^{+}$ & 0.038 & 1.000 & $0.704^{*}$ \\
SOFA & $0.224^{*}$ & 0.027 & $0.704^{*}$ & 1.000 \\
\end{tabular}

APACHE II: Acute Physiology and Chronic Health Evaluation II Score, GCS: Glasgow Coma Scale Score, MPV: Mean Platelet Volume, NLR: Neutrophil-to-Lymphocyte Ratio, PLR: Platelet-to-Lymphocyte Ratio, RDW: Red Blood Cell (Erythrocyte) Distribution Width, SOFA: Sequential Organ Failure Assessment Score, WBC: White Blood Cells Count; * Correlation is statistically significant at the 0.05 level, ${ }^{+}$Correlation is statistically significant at the 0.01 level.

\section{DISCUSSION}

In the evaluation of the scoring systems compared in our study, we found that the NLR and the PLR are more powerful, faster, and simpler methods than the APACHE II and SOFA scores in predicting mortality.
As a result of the sepsis it causes, and due to multiple organ failures caused by sepsis, pneumonia continues to be a worldwide problem with high morbidity and mortality rates ${ }^{11}$. Despite the advances in diagnosis and treatment, pneumonia is a common disease with high mortality ${ }^{15}$. The combined use of clinical findings and evaluation scores are important indicators in identifying patients at risk. The uses of such indicators are increasingly employed to predict the prognosis of pneumonia and to guide the correct antibiotic treatment ${ }^{16,17}$.

Researchers have sought for a practical and appropriate scoring method in intensive care units for many years in an attempt to reflect the intensity of the stress and systemic inflammation in critically ill patients who had witnessed a shock, multiple traumas, major surgery or sepsis, and this query of theirs led to the introduction of organ failure scoring systems such as the APACHE II and SOFA ${ }^{12,18}$.

In addition to the scoring systems above, the NLR was also examined as a marker of infection in patients hospitalized in the intensive care unit, and its good correlation with the severity and outcome of the disease was detected when compared to the APACHE II and SOFA scoring systems ${ }^{12,15}$. Although neutrophilia is well known to clinicians as an indicator of infection, clinicians know less about lymphocytopenia, which is another possible indicator of infection. Recently, the ratio between neutrophil and lymphocyte counts as a marker of many clinical conditions has been increasingly used ${ }^{18-20}$.

In addition, in cases such as sepsis, where inflammation is intense, an increase in the platelet counts occurs due to their accelerated expression following the increase in their breakdown ${ }^{21}$. However, the PLR was used as a new marker in conditions such as acute renal failure, cardiovascular diseases, and COPD ${ }^{9,22,23}$. 
Unlike other studies, we found that the male gender increased the mortality risk by 2.7 times and also decreased the survival time $e^{5,9,24}$. We associated this situation with the higher number of COPD diagnoses in the male gender and the increased likelihood of COPD to be pneumonia.

In Shimoyama et al.' ${ }^{4}$ study, the predictive value NLR, and the PLR as a prognostic factor in mortality was not found to be significant compared to the SOFA scores. In Kumar et al.'s ${ }^{9}$ study the NLR and the PLR and in Wang et al.' ${ }^{25}$ study the NLR and the APACHE II scores were found to be more meaningful than other scoring systems in predicting mortality. In the study published by Yildiz et al. ${ }^{26}$ while the APACHE II score was found to be more effective, but PLR ineffective in predicting mortality. In our study, the effects of the NLR and the PLR, and the APACHE II and SOFA scores in predicting mortality were found to be significant. We attributed the predictive significance of all scoring parameters compared in our study to the fact that they were calculated in hospitalized patients that received a specific diagnosis such as pneumonia.

Observing the risk rates in some studies, we can see that demographic data do not create a change in mortality risk rates ${ }^{5,9}$. In Kumar et al.'s ${ }^{9}$ study, there was $15 \%$ increase in mortality for each one unit increase in the PLR, while Akıllı et al. ${ }^{5}$ stated that the NLR was better than the APACHE II score in evaluating the risk rates. In our study, each one unit increase in the NLR increased the risk of death by $5 \%$. Wang et al. found that if the NLR was $>14$, mortality increased by $53 \%$ for each one-unit increase in NLR25. As in our study, Shimoyama et al.' $s^{4}$ study showed that the risk rates estimated using SOFA scores were higher compared to NLR. In addition, we found that each one unit increase in the SOFA scores increased the risk of death by $13 \%$. We concluded that this is due to the fact that the numerical value of the SOFA lies in a narrow range between 0-20, whereas there is no upper limit for the numerical value for the NLR.
Considering the statistical power of the prognostic markers we used in predicting mortality, the NLR was found to be the most powerful test in our study. We see that the SOFA score was reported to be the most powerful test in Shimoyama et al.' $s^{4}$ study. Similarly, in Kumar et al.' $s^{9}$ study on 181 patients, the power of the PLR was found similar to that in our study. In the study where 368 patients were included to assess whether routine blood tests could determine the prognosis in COPD disease, Xiong et al. ${ }^{27}$ found that the power of the NLR in predicting mortality was higher than that in our study. We believe this is due to the smaller sample size that we had. In Naqvi et al.' ${ }^{28}$ study which examined the APACHE II and SOFA scores in 98 patients, the value of the AUC in the ROC curve of the APACHE II and SOFA scores was found to be higher than that in our study. We attribute the reason for this discrepancy to the fact that the researchers evaluated all intensive care patients regardless of their diagnosis.

In the evaluation of the sensitivity and specificity values according to the NLR cut-off values, in Shimoyama et al.'s ${ }^{4}$ study, the cut-off value of 13.28 had a sensitivity of $62.5 \%$, and the specificity of $66.7 \%$, while in the study of Xiong et al. ${ }^{27}$ its sensitivity, and specificity were found to be $85.8 \%$ and $89.7 \%$, respectively. In Kaushik et al.' ${ }^{24}$ study, the NLR was examined on the first and fifth days, and it was observed that the NLR calculated on the first day was not significant, while its sensitivity and specificity were higher on the fifth day. In our study, we determined that NLR cut-off value of 11.3 had the sensitivity of 81.3, and specificity of 77.1. We found that the values in our study were similar to those from other studies ${ }^{4,9,27}$.

In the study conducted by Kumar et al. ${ }^{9}$, it was reported that with a cut-off value of 235, PLR had the sensitivity of $63 \%$ and the specificity of $74 \%$. The authors suggested that the PLR $\geq 235$ was significantly associated with 90-day mortality, a finding that may provide prognostic guidance for 
clinicians 9 . In another study conducted in Japan, the sensitivity, and specificity of the PLR with a cut-off value of 590.44, were determined as $62.5 \%$ and $66.7 \%$, respectively ${ }^{4}$. In our study, we determined the cut-off value of the PLR to be 227 that had a sensitivity of $67.2 \%$ and specificity of $62.5 \%$. We concluded that the lower sensitivity and specificity of the PLR compared to the NLR and the APACHE II scores was due to the statistical insignificance of the platelet count per se on predicting mortality.

In Akıllı et al.' $\mathrm{s}^{5}$ study, any correlation was not found between the NLR and the APACHE II, SOFA, and the GCS scores. In Velisaris et al.' ${ }^{8}$ study investigating the NLR and sepsis severity scoring systems at admission, the data of 50 patients with an average age of 68.4 years were analyzed and it was determined that the NLR was positively correlated with the SOFA and the APACHE II scores, and that the WBC count had a weak positive correlation with the SOFA and the APACHE II scores. On the other hand, weakly positive correlation were detected between the WBC count vs NLR; the WBC count vs the APACHE II scores; the NLR vs the APACHE II scores, and the NLR vs the SOFA scores, while the APACHE II, and the SOFA scores were positively correlated in our study. We also observed a negative correlation between the GCS and the APACHE II scores and between the GCS and the SOFA scores. This is thought to be due to the fact that the GCS was included in the APACHE II and the SOFA scores.

There are some limitations in our study. First, we do not know whether the parameters we evaluated were affected by height and weight of the patients-we could not reach these data in our study. Second, our study was planned as a single-center and retrospective research, thus, our results should be supported by multicenter and prospective studies.

\section{CONCLUSION}

As an indicator of mortality, the NLR and the PLR were found to be simple, inexpensive, fast, and independent methods in comparison to the APACHE II and the SOFA scores. The combined use of these values can help predict mortality more accurately. Physicians should never ignore the complex picture in clinical presence of pneumonia and consequent sepsis and remember that no scoring system can take place of the systematic approach followed in the evaluation of sepsis patients.

\section{REFERENCES}

1. Knaus WA, Zimmerman JE, Wagner DP, Draper EA, Lawrence DE. APACHE-acute physiology and chronic health evaluation: a physiologically based classification system. Crit Care Med. 1981;9:591-7. [CrossRef]

2. Maccariello ER, Valente C, Nogueira L, et al. Performance of six prognostic scores in critically ILL patients receiving renal replacement therapy. Rev Bras Ter Intensiva. 2008;20:115-23. [CrossRef]

3. Pettilä V, Pettilä M, Sarna S, Voutilainen P, Takkunen O. Comparison of multiple organ dysfunction scores in the prediction of hospital mortality in the critically ill. Crit Care Med. 2002;30:1705-11. [CrossRef]

4. Shimoyama Y, Umegaki O, Agui T, Kadono N, Minami T. Neutrophil to lymphocyte ratio and platelet to lymphocyte ratio are superior to other inflammationbased prognostic scores in predicting the mortality of patients with gastrointestinal perforation. JA Clin Reports. 2017;3:49. [CrossRef]

5. Akilli NB, Yortanlı M, Mutlu $\mathrm{H}$, et al. Prognostic importance of neutrophil-lymphocyte ratio in critically ill patients: short- and long-term outcomes. Am J Emerg Med. 2014;32:1476-80. [CrossRef]

6. Kayrak M, Erdoğan Hi, Solak Y, et al. Prognostic value of neutrophil to lymphocyte ratio in patients with acute pulmonary embolism: a restrospective study. Hear Lung Circ. 2014;23:56-62. [CrossRef]

7. Azab B, Jaglall N, Atallah JP, et al. Neutrophil-lymphocyte ratio as a predictor of adverse outcomes of acute pancreatitis. Pancreatology. 2011;11:445-52. [CrossRef]

8. Velissaris D, Pantzaris ND, Bountouris P, Gogos C. Correlation between neutrophil-to-lymphocyte ratio and severity scores in septic patients upon hospital admission. A series of 50 patients. Rom J Intern Med. 2018;56:153-7. [CrossRef]

9. Kumar P, Law S, Sriram KB. Evaluation of platelet lymphocyte ratio and 90-day mortality in patients with acute exacerbation of chronic obstructive pulmonary disease. J Thorac Dis. 2017;9:1509-16. [CrossRef]

10. Rajagopal P, Ramamoorthy S, Grace Jeslin A. Utility of haemogram parameters in mortality risk prediction of critically ill patients. J Evol Med Dent Sci. 2018;7:1024-9. 
O.F. Altas and M. Kizilkaya, The Effects of Neutrophil-Lymphocyte Ratio, Platelet-Lymphocyte Ratio and Prognostic Markers in Determining the Mortality in Patients Diagnosed With Pneumonia in Intensive Care

[CrossRef]

11. Mandell LA, Wunderink RG, Anzueto A, et al. Infectious Diseases Society of America/American Thoracic Society consensus guidelines on the management of communityacquired pneumonia in adults. Clin Infect Dis. 2007;44 Suppl 2:S27-72. [CrossRef]

12. Knaus WA, Draper EA, Wagner DP, Zimmerman JE. APACHE II: a severity of disease classification system. Crit Care Med. 1985;13:818-29. [CrossRef]

13. Karabiyik L. Scoring systems in intensive care. Journal of Intensive Care. 2010;9:129-43. [CrossRef]

14. Vincent JL, Moreno R, Takala J, et al. The SOFA (Sepsisrelated Organ Failure Assessment) score to describe organ dysfunction/failure: On behalf of the Working Group on Sepsis-Related Problems of the European Society of Intensive Care Medicine. Intensive Care Med. 1996;22:707-10. [CrossRef]

15. de Jager CPC, Wever PC, Gemen EFA, et al. The Neutrophillymphocyte count ratio in patients with communityacquired pneumonia. PLoS One. 2012;7:e46561. [CrossRef]

16. Christ-Crain M, Muller B. Biomarkers in respiratory tract infections: diagnostic guides to antibiotic prescription, prognostic markers and mediators. Eur Respir J. 2007;30:556-73. [CrossRef]

17. Kopterides P, Siempos II, Tsangaris I, Tsantes A, Armaganidis A. Procalcitonin-guided algorithms of antibiotic therapy in the intensive care unit: A systematic review and meta-analysis of randomized controlled trials. Crit Care Med. 2010;38:2229-41. [CrossRef]

18. Zahorec R. Ratio of neutrophil to lymphocyte counts-rapid and simple parameter of systemic inflammation and stress in critically ill. Bratisl Lek Listy. 2001;102:5-14. PMID: 11723675.

19. Wyllie DH, Bowler ICJW, Peto TEA. Relation between lymphopenia and bacteraemia in UK adults with medical emergencies. J Clin Pathol. 2004;57:950-5. [CrossRef]

20. de Jager CPC, van Wijk PTL, Mathoera RB, de JonghLeuvenink J, van der Poll T, Wever PC. Lymphocytopenia and neutrophil-lymphocyte count ratio predict bacteremia better than conventional infection markers in an emergency care unit. Crit Care. 2010;14:R192. [CrossRef]

21. von Hundelshausen P, Weber C. Platelets as immune cells. Circ Res. 2007;100:27-40. [CrossRef]

22. Van der Lelie J, Von dem Borne AK. Increased mean platelet volume in septicaemia. J Clin Pathol. 1983;36:693-6. [CrossRef]

23. Zheng C-F, Liu W-Y, Zeng F-F, et al. Prognostic value of platelet-to-lymphocyte ratios among critically ill patients with acute kidney injury. Crit Care. 2017;21:238. [CrossRef]

24. Kaushik R, Gupta M, Sharma M, et al. Diagnostic and prognostic role of neutrophil-to-lymphocyte ratio in early and late phase of sepsis. Indian J Crit Care Med. 2018;22:660-3. [CrossRef]

25. Wang Y, Ju M, Chen C, et al. Neutrophil-to-lymphocyte ratio as a prognostic marker in acute respiratory distress syndrome patients: a retrospective study. J Thorac Dis. 2018;10:273-82. [CrossRef]

26. Yildiz A, Yigit A, Benli AR. The impact of nutritional status and complete blood count parameters on clinical outcome in geriatric critically ill patients. J Clin Med Res. 2018;10:588-92. [CrossRef]

27. Xiong W, Xu M, Zhao Y, Wu XL, Pudasaini B, Liu JM. Can we predict the prognosis of COPD with a routine blood test? Int J Chron Obstruct Pulmon Dis. 2017;12:615-25. [CrossRef]

28. Naqvi IH, Mahmood K, Ziaullaha S, Kashif SM, Sharif A. Better prognostic marker in ICU - APACHE II, SOFA or SAP II! Pakistan J Med Sci. 2016;32:1146-51. [CrossRef] 